\title{
Binswanger and phenomenology applied to mania
}

\section{Binswanger e a fenomenologia aplicada à mania}

\author{
Ignacio Iglesias Colillas ${ }^{1}$
}

\begin{abstract}
Binswanger has a fundamental appreciation: he refuses to accept the so-called "Faculty Psychology", and his thoughts and arguments are especially interesting for focusing at this point. We employ the analyses made by the author as an example of this and also as a focus of study of the maniac subjectivity. I would like to especially highlight the concept of "Ideenflucht", the «flight of ideas», that later became pathognomonic of mania. It is also interesting to pay attention to the use that Binswanger made of Heidegger's ideas, mainly taken from "Sein und Zeit", because in this exceptional case, in which - as in many others - a psychiatrist supports his theoretical developments in a philosopher, Heidegger himself criticized the use that Binswanger made of his concepts. The place where we can circumscribe these issues is the "Zollikon Seminars", given by Heidegger in Switzerland between 1959 and 1969 at the invitation of Dr. M. Boss.
\end{abstract}

Keywords: Binswanger; Phenomenology; Mania; Heidegger critics

\section{Resumo}

Binswanger se recusa a aceitar a chamada "Faculdade Psicológica", seus pensamentos e argumentos são especialmente interessantes para se dedicar a esse assunto. Empregamos as análises feitas pelo autor sobre essa matéria e também sobre seus estudos da subjetividade na mania. Gostaríamos de destacar especialmente o conceito de "Ideenflucht", "fuga de ideias", que mais tarde se tornou patognomônico da mania. É interessante prestar atenção também ao uso que Binswanger fez das ideias de Heidegger, tomadas principalmente de "Sein und Zeit", "Ser e Tempo" porque, neste caso notável como em muitos outros - no qual um psiquiatra sustenta os seus desenvolvimentos teóricos a partir de um filósofo, o próprio Heidegger criticou o uso que Binswanger fez de seus conceitos. Podemos circunscrever essas críticas pela análise dos "Seminários de Zollikon", ministrados por Heidegger na Suíça entre 1959 e 1969, a convite do Dr. M. Boss.

Palavras-chave: Binswanger; Fenomenologia; Mania; Críticos Heidegger

\footnotetext{
${ }^{1}$ Psychoanalyst. Psychopathology teacher, researcher and doctoral candidate at University of Buenos Aires, Argentina. Contato: ignacioiglesiascolillas@gmail.com
}

Recebido: 13.02 .2018

Aceito: 20.04.2018 


\section{Introduction}

The following presentation part of a major research project dedicated to reviewing what modern biological psychiatry calls "bipolar disorders" and "bipolar spectrum". Our essay is divided in two parts. In the first we try to isolate and circumscribe the main epistemological assumptions of mainstream biological psychiatry, by studying the DSM's "mental disorder" category, the so-called "mood disorders" and Akiskal's "bipolar spectrum". In Part II, this research led us to study many classical psychiatry authors, especially Griesinger, Kraepelin and Binswanger from the German school, and Falret, Baillarger, Séglas and Cotard from the French. We found that these authors had one common fundamental appreciation: they all refuse to accept the so-called «Faculty Psychology», and Binswanger's thoughts and arguments are especially interesting for focusing at this point.

We tried to make use of the analyses made by the author as an example of this and also as a focus of study of the maniac subjectivity. We would like to especially highlight the conception of the "Ideenflucht", the "flight of ideas", that later became pathognomonic of mania. It is also interesting to draw our attention to the use that Binswanger made of Heidegger's ideas, mainly taken from "Sein und Zeit", because in this exceptional case, in which - as in many others - a psychiatrist supports his theoretical developments in a philosopher, Heidegger himself criticized the use that Binswanger made of his developments. The place where we can circumscribe these issues is the "Zollikon Seminars", given by Heidegger in Switzerland between 1959 and 1969 at the invitation of Dr. M. Boss.

\section{Binswanger's "Ideenflucht"}

Before Binswanger's rework of the notion of the Ideenflucht, mainstream psychiatry conceived mania primarily as an association or as a representation disorder. For example: Bumke, Wernicke, Kraepelin (Kraepelin, 2012; Kraepelin; Kalhbaum; Hecker, 1996), Mendel and Ziehen supported this point of view (Binswanger, 2007a). But Kraepelin is one of the most important authors to criticize for our research, because Akiskal and his group called themselves "neo-kraepelinians".

But Binswanger pointed out that these types of studies necessarily fail because they lack of a methodological and phenomenological study of temporal consciousness, and also because neither associations nor representations can be understood as isolated analytical units. Besides, both terms remain closely linked to the so-called "Faculty Psychology", the XVII century school of thought developed after the philosophical work of T. Reid (1710-1796), D. Stewart (1753-1828) and the Scottish school of common sense. This doctrine, which had a strong impact in all XIX century psychopathology, divided the mental phenomena into three supposedly separated spheres: emotions, reason and will.

Inspired by Husserl and Heidegger, Binswanger suggests the "existential anthropology" to save those methodological impasses, trying to interpret the flight of ideas as an existential possibility. Then the main question will be the following: what is the anthropological structure of mania? Following Heidegger's method, Binswanger intends to reach the heart of the flight of ideas as an existential possibility.

Instead of pointing at classifying the flight of ideas as a mere symptom - although pathognomonic of mania -, or as a character disorder, that is, a type of deviation of a supposed normality, Binswanger will try to contemplate it as a way of being, mainly characterized by a sort of "jumping modality" of 
being (Binswanger, 2007a). But we could ask ourselves: where can we observe - from a methodological point of view - this singular way of being? In verbal statements. This means that Binswanger is paying special attention to language, more precisely to discourse, like Griesinger already did in 1845 (Griesinger, 1997; Iglesias Colillas, 2016). Considering that all the terms related to "mood" are very difficult to circumscribe following a serious clinical method, we prefer instead to highlight listening to the patient's discourse and statements. This point of view intends to reject always from a methodological and scientific approach - the massive spread of very nonspecific diagnoses, like Akiskal's "bipolar spectrum" (Akiskal et al., 2006), which does not take into account the distinction between neurotic and psychotic disorders, promoting the "labelling" of common mood variations, like sadness and grief, which are perfectly normal and should not require medication. Therefore, we would like to promote the attitude of rejecting the medicalization of the being, and we strongly believe that this discussion should take place in the scientific field.

According to Binswanger's point of view, maniacs tend to jump and skip some particular elements of language which are essential for the production of meaning in a particular sentence, and this appears as the phenomena of the "flight of ideas". But Binswanger goes beyond and raises his inquiry to an ontological dimension by asking -inspired in Heidegger - for the anthropological structure of mania.

Thus, it is from this perspective that the author suggests the "jumping" metaphor to understand the maniac discourse, embedded in this anthropological structure. Within psychoanalysis, Lacan will later follow these ideas - and so will many others, especially from Winnicott - for characterizing maniac discourse too (mainly as "drive to discourse", "flood of words", "a game with the sonorous substance of language" etc.) (Lacan, 2012; Winnicott, 1979).

Binswanger characterizes this "jumping" or slippery way of being in the following way: within the objective space as a narrowing or as a constriction of space; within the region of objective time as a shortening of time; within the spatiality of existence in general as an approach or distance from objects in space [...]; within temporality as unconnected moments; within the sphere of significance in general as a playful activity, not autonomous, dependent of the respective space and time circumstances and the respective vital necessities. Also within the sphere of significance in general they usually find kinships between meanings, thus, meanings are interchangeable. Consequentially, this also happens within the syntactic and grammatical organization of discourse as a whole. Within the social region, as a disappearance of frontiers of the social structure; within personal history and inner life as suddenness and overlapping of life events (Binswanger, 2007a).

Up to here we have synoptically shown how Binswanger put into question the so-called "Faculty Psychology" by laying the weight on phenomenology developments (Binswanger, 2007b), propounding Heidegger's "existential anthropology" and Husserl's "intentionality" for understanding maniac discourse. But what was Heidegger's point of view about this use of his terminology?

\section{Heidegger's perspective}

The way Binswanger addresses the "maniac world", his grounds of belief and treatment of the subject seem to be mainly inspired by Heidegger's concept of "Being-in-the-World". But this term is just a component of a major ontological structure called Dasein. 
In Sein und Zeit, when Heidegger makes reference to the ground concepts of sciences, he sharply distinguishes two levels: the ontic and the ontological, which implies inquiring for the conditions of possibility of Being (Bedingungen der Möglichkeit) and, at last, of "Being-in-the-World". "World" here means, in an ontological sense, "worldhood" (Weltheit), the condition of possibility for the existence of any particular world, including the "maniac world" in the sense that Binswanger makes use of it. In this sense, the "world" is a warp thread of references and possible meanings that functions as a horizon of intelligibility of existence.

In the Zollikon Seminars, Heidegger in fact showed that he wasn't very happy with Binswanger's way of reading him. Heidegger argued that the "psychiatric analyse of Dasein" is based on a trimmed notion of Dasein, only based on the "Being-in-the-World". Heidegger states that this is the first structure that must become visible in the approach to understanding the being, but it is certainly not the only one.

The comprehension of being - asserts the author - is the fundamental determination of Dasein in itself [...]. The «psychiatric analysis of Dasein» works with a trimmed Dasein, from which the fundamental feature is taken out [...]. The separation between the fundamental ontology and the psychiatric analysis of Dasein (carried out by Binswanger), justified at first sight, it's really a disregard of the relationships between fundamental ontology and regional ontology; the last one is presupposed by all sciences, including psychiatry. The fundamental ontology is the thinking that moves in the base of the entire ontology. None of these (regional ontologies) can leave behind the foundation, let alone the regional ontology of psychiatry as a study that moves in the realm of the substance of human being [...]. Being-in-the-World is not a condition of possibility of Dasein (Binswanger, Über Sprache und Denken, p. 209), it is the other way around (Heidegger, 2007: 253-255).

Afterwards, Heidegger adds: "Dasein is not "subject", but, in any case, its condition of possibility (Heidegger, 2007: 257).

On the other hand, Heidegger criticizes Binswanger for being somewhat naïve by speaking, related to the phenomenological method, about the pretention of reaching an "analysis of phenomena that reveals only those determinations that belong to the phenomenon itself", since the question is "What does "describing" mean? Every description is an interpretation!" (Heidegger, 2007: 256), claims Heidegger.

\section{Preliminary results}

At last, it is worth mentioning the fact that Binswanger supports Kraepelin's "manic-depressive madness" (Binswanger, 1987), which is not exactly immune to severe epistemological critics. For example, according to P. Bercherie, manic-depressive madness it is not exactly a neat entity; their borders sometimes melt with the frontiers of paranoia and some circular and other agitated presentations of dementia praecox, for example.

In any case, we can never avoid the semiotic and hermeneutic issues of our discipline, and this small contribution only intends to promote the effort of maintaining this essential field of inquiries open. We 
highlighted these clinical issues because we think that the so-called "bipolar disorders" carry within many non-explicit assumptions, for example, that what they call "mood" or even "mental disorder" is not yet a scientific category. It is very important to be very careful with the use of our terms, so as they are not hollow and vain notions, which sometimes seem to be exclusively at the service of psychopharmacology, that is, the pharmaceutical industry.

Beyond the world and the ways of being a patient established by our biomedical culture and the biomedical psychiatry, there are still many relevant clinical questions waiting for an answer. For example: is mania a momentum or phase of a "circular insanity"? Is it a failure of temporality? Is it an election of the Being? Or is it that mania is, like Freud early suggested, a defensive reaction against melancholia, characterized by the impossibility of losing and loving? Beyond the critics, questions, and arguments for and against, I would like to highlight that both Freud and Binswanger always focused on mania from the point of view of language, meaning and discourse. After all, up to now, do we really have any serious clinical method that sets aside the fact that the only way we have to reach the ontology is mainly through discourse? 


\section{References}

Akiskal, H., Cetkovich-Bakmas, M., García-Bonetto, G., Stejilevich, S., \& Vázquez, G. (2006). Trastornos bipolares: Conceptos clínicos, neurobiológicos y terapéuticos. Buenos Aires: Médica Panamericana.

Binswanger, L. (1987). Mélancolie et manie. Paris: Presses Universitaires de France.

Binswanger, L. (2007a). Sobre la fuga de ideas (1933). En G. Napolitano (comp.). Perspectivas fenomenológicas en psicopatología. Buenos Aires: De la Campana.

Binswanger, L. (2007b). Sobre la fenomenología. In L. Binswanger, A. Warburg, La curación infinita:Historia clínica de Aby Warburg. Buenos Aires: Adriana Hidalgo.

Griesinger, W. (1997). Patología y terapéutica de las enfermedades mentales. Buenos Aires: Polemos.

Heidegger, M. (2007). Seminarios de Zollikon: Protocolos, diálogos, cartas. México: Jitanjáfora.

Iglesias Colillas, I. (2016). Los trastornos bipolares: una revisión crítica: psicopatología, historia y epistemología. Buenos Aires: Letra Viva.

Kraepelin, E., Kalhbaum, K., \& Hecker, E. (1996). La locura maníaco-depresiva: la catatonía, la hebefrenia. Buenos Aires: Polemos.

Kraepelin, E. (2012). La locura maníaco-depresiva. Madrid: Biblioteca de los Alienistas del Pisuerga.

Lacan, J. (2012). Televisión. In J. Lacan, Otros escritos. Buenos Aires: Paidós.

Winnicott, D. W. (1979). La defensa maníaca. In D. W. Winnicott, Escritos de pediatría y psicoanálisis. Barcelona: Laia. 